\title{
Bacillus ehimensis sp. nov. and Bacillus chitinolyticus sp. nov., New Chitinolytic Members of the Genus Bacillus
}

\author{
KEN-ICHI KUROSHIMA, ${ }^{1}$ TAKESHI SAKANE, ${ }^{1 *}$ RENKICHI TAKATA, ${ }^{2}$ AND AKIRA YOKOTA ${ }^{1} \dagger$ \\ Institute for Fermentation, Osaka, Yodogawa-ku, Osaka 532, ${ }^{1}$ and Department of \\ Agriculture, Ehime University, Tarumi, Matsuyama $790,{ }^{2}$ Japan
}

\begin{abstract}
Five chitin-degrading bacteria were isolated from soil. These organisms were strictly aerobic and rod shaped, formed spores, contained menaquinone 7 as the major isoprenoid quinone and 12-methyltetradecanoic acid as the major cellular fatty acid, and had guanine-plus-cytosine contents of 51.3 to $54.9 \mathrm{~mol} \%$, characteristics which indicate that they belong to the genus Bacillus. These five strains were divided into two groups on the basis of physiological characteristics and the results of a DNA-DNA hybridization study. As low levels of DNA relatedness were found between our isolates and previously described Bacillus strains, we propose that our isolates should be classified in two new Bacillus species, Bacillus ehimensis and Bacillus chitinolyticus. The type strains of $B$. ehimensis and $B$. chitinolyticus are strains IFO 15659 and IFO 15660, respectively.
\end{abstract}

Chitin is a polymer of $\beta$-1,4-linked $N$-acetylglucosamine and is widely distributed in nature as a structural component of crustacea, fungi, protozoa, and insects. The polymer is degraded enzymatically by the sequential action of two hydrolytic enzymes chitinase (EC 3.2.1.14) and chitobiase (EC 3.2.1.29) (12). Two types of chitinase activity, exochitinase activity and endochitinase activity, have been distinguished. Exochitinase activity is defined as a progressive activity that starts at the nonreducing ends of chitin chains and successively releases diacetylchitobiose units, while endochitinase activity involves random cleavage at internal points in chitin chains (25). Microbial degradation of chitin has been observed with various bacteria, especially bacteria isolated from marine environments. Well-known chitinolytic bacteria include members of the genera Alteromonas (2), Bacillus (6), Chitinophaga (27), Cytophaga (22), Flexibacter (22), Herpetosiphon (24), Lysobacter (23), Micromonospora (10), Paenibacillus (6), Photobacterium (3), Planomonospora (10), Serratia $(15,16)$, Streptomyces (4), and Vibrio (3). In the genus Bacillus, chitindegrading activity has been found in the type strains of seven species (Bacillus brevis, Bacillus laterosporus, Bacillus lentus, Bacillus licheniformis, Bacillus megaterium, Bacillus thiaminolyticus, and Bacillus thuringiensis) and in some other strains of Bacillus species $(6,21,31)$. Three chitinolytic Bacillus species, Bacillus alvei, Bacillus macerans, and Bacillus pulvifaciens, have been transferred to the genus Paenibacillus as Paenibacillus alvei, Paenibacillus macerans, and Paenibacillus pulvifaciens, respectively $(1,9)$.

We searched soil samples for chitinolytic bacteria and obtained five isolates. These bacteria were considered members of the genus Bacillus but could not be assigned to any previously described species of the genus. The isolates were divided into two groups on the basis of physiological characteristics and DNA relatedness data, and two new species, Bacillus chitinolyticus and Bacillus ehimensis, are described below.

* Corresponding author. Mailing address: Institute for Fermentation, Osaka, 17-85, Juso-honmachi 2-chome, Yodogawa-ku, Osaka 532, Japan. Phone: 81-6-300-6555. Fax: 81-6-300-6814.

$\dagger$ Present address: Institute of Molecular and Cellular Biosciences, The University of Tokyo, Bunkyo-ku, Tokyo 113, Japan.

\section{MATERIALS AND METHODS}

Isolation. Soil samples were obtained from five garden sites in Matsuyama, Ehime Prefecture, Japan, and three forest sites in Kaya, Kagoshima Prefecture, Japan. To isolate organisms, $1 \mathrm{~g}$ of a soil sample was suspended in $2 \mathrm{ml}$ of sterile distilled water, and aliquots of the resulting suspension were inoculated onto M9 agar plates (14) supplemented with $0.1 \%$ yeast extract and $0.3 \%$ colloidal chitin (Funakoshi, Tokyo, Japan). After incubation for 3 days at $30^{\circ} \mathrm{C}$, about 2,000 colonies per sample were examined for chitin-degrading activity, and the colonies that had clear halos were subcultured onto Luria-Bertani agar, which contained $1 \%$ peptone, $0.5 \%$ yeast extract, $0.5 \% \mathrm{NaCl}$, and $1.5 \%$ agar $(\mathrm{pH}$ 7.0).

Bacterial strains and culture conditions. The bacterial strains used in this study are listed in Table 1 . The biomass used for isoprenoid quinone and cellular fatty acid analyses was prepared by growing the strains for 1 day at $28^{\circ} \mathrm{C}$ with shaking in Luria-Bertani medium. The cells were harvested by centrifugation, washed with distilled water, and lyophilized.

Morphological and physiological characteristics. Motility was determined with an optical microscope by the hanging drop method. Catalase activity was determined by bubble formation in a $3 \%$ hydrogen peroxide solution. Oxidase activity was determined by oxidation of $1 \%$ tetramethyl-p-phenylenediamine on filter paper. Hydrolysis of casein, hydrolysis of gelatin, and hydrolysis starch were determined as described by Cowan and Steel (7). Hydrolysis of chitin was determined by a plate method. An actively growing culture of each strain was inoculated onto CT-6 agar containing colloidal chitin (23). After incubation for $3,7,10$, and 14 days, the presence of clear halos surrounding the colonies was evidence of chitin degradation. Other phenotypic characteristics were determined by the methods described by Claus and Berkeley (5). All tests were performed at $28^{\circ} \mathrm{C}$

Analysis of isoprenoid quinones. Menaquinones were extracted from $200 \mathrm{mg}$ of freeze-dried cells with chloroform-methanol $(2: 1$, vol/vol $)$, separated by thinlayer chromatography with hexane-dimethyl ether $(85: 15)$ as the solvent, extracted with diethyl ether, dried under a nitrogen stream, and then analyzed by high-performance liquid chromatography (HPLC) with a model LC-5A apparatus (Shimadzu Co., Ltd., Kyoto, Japan) equipped with a Zorbax octyldecyl silane column ( 4.6 by $150 \mathrm{~mm}$ ). Methanol-isopropyl ether (7:1) was used as the mobile phase.

Analysis of cellular fatty acids. Fatty acids were extracted from $50 \mathrm{mg}$ of freeze-dried cells by acid methanolysis and were analyzed with a model GC-9A gas-liquid chromatograph (Shimadzu Co., Ltd.) equipped with a glass column (2 mm by $5 \mathrm{~m}$ ) containing $10 \%$ diethylene glycol succinate on Chromosorb W at $180^{\circ} \mathrm{C}(29)$.

DNA base composition. DNA was isolated from bacterial cells grown overnight in Luria-Bertani medium containing $0.5 \%$ glucose at $28^{\circ} \mathrm{C}$ by the method of Saito and Miura (26). The $\mathrm{G}+\mathrm{C}$ content of the DNA was determined by the method of Mesbah et al. (13); after the DNA was treated with $P_{1}$ nuclease and alkaline phosphatase, the $\mathrm{G}+\mathrm{C}$ content was determined by HPLC with a model LC-6AD apparatus (Shimadzu Co., Ltd.) equipped with a Cosmosil $5 \mathrm{C}_{18}$-AR column ( 4.6 by $150 \mathrm{~mm}$; Nacalai Tesque, Inc., Kyoto, Japan). The mobile phase used was $0.2 \mathrm{M}$ ammonium phosphate-acetonitrile (40:1, vol/vol).

DNA-DNA hybridization. Levels of DNA relatedness were determined fluorometrically by the method of Ezaki et al. (8) by using biotinylated DNA. 
TABLE 1. Bacterial strains used

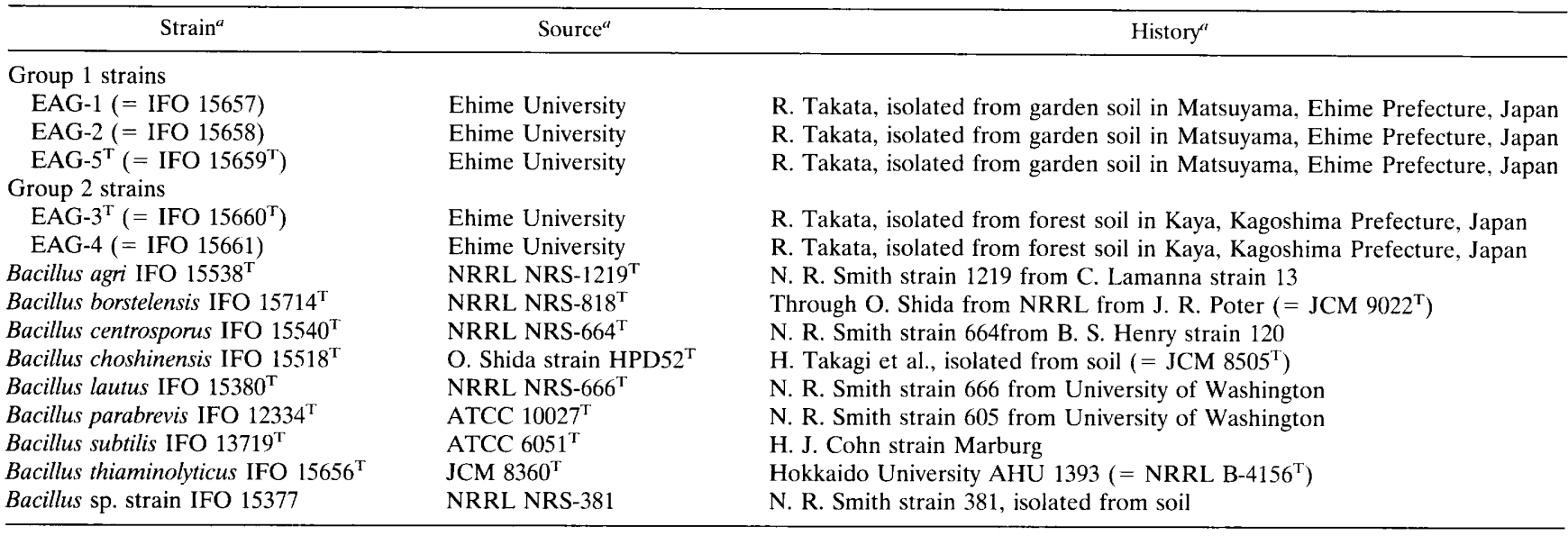

"IFO, Institute for Fermentation, Osaka, Japan; ATCC, American Type Culture Collection, Rockville, Md.; JCM, Japan Collection of Microorganisms, Saitama, Japan; NRRL, Agricultural Research Service Culture Collection, National Center for Agricultural Utilization Research, Peoria, Ill.

\section{RESULTS AND DISCUSSION}

Chitinolytic strains EAG-1, EAG-2, and EAG-5 ${ }^{\mathrm{T}}$ ( $\mathrm{T}=$ type strains) were isolated from three garden soil samples collected in Matsuyama, and strains EAG-3 $3^{\mathrm{T}}$ and EAG-4 were isolated from two forest soil samples collected in Kaya. Tables 2 and 3 show the morphological, biochemical, and chemotaxonomic characteristics of these organisms. These strains belong to the genus Bacillus because they are strictly aerobic, produce rodshaped cells and oval spores in swollen sporangia (Fig. 1), are motile by means of peritrichous flagella, and contain menaquinone 7 as the major quinone and 12-methyltetradecanoic acid (anteiso- $\mathrm{C}_{15: 0}$ ) as the major cellular fatty acid.

The $\mathrm{G}+\mathrm{C}$ contents of the five new isolates ranged from 51.3 to $54.9 \mathrm{~mol} \%$. The previously described chitinolytic Bacillus strains (6) include B. brevis ATCC $8246^{\mathbf{T}}, B$. laterosporus ATCC $64^{\mathrm{T}}$, B. lentus NRRL B-369 $9^{\mathrm{T}}$, B. licheniformis ATCC $14580^{\mathrm{T}}, B$. megaterium ATCC $14581^{\mathrm{T}}$, and $B$. thuringiensis ATCC $10792^{\mathrm{T}}$, and the $\mathrm{G}+\mathrm{C}$ contents of these strains range from 34 to $47 \mathrm{~mol} \%$
(5). Therefore, our isolates can be clearly differentiated from these six previously described chitinolytic species on the basis of $\mathrm{G}+\mathrm{C}$ contents. Although some Bacillus strains, including "Bacillus apirius" NRRL B-1438, Bacillus circulans WL-12A, Bacillus sp. strain ATCC 4513 (previously named "Bacillus chitinosporus") (11), and B. thiaminolyticus S327 to S330 (21), have been referred to as chitinolytic $(6,29)$, they are not type strains, and their $\mathrm{G}+\mathrm{C}$ contents have not been determined.

Table 4 shows the levels of DNA relatedness between the new isolates and the type strains of previously described $B a$ cillus species which are mesophilic and have $\mathrm{G}+\mathrm{C}$ contents of more than 49 mol\%. Bacillus sp. strain IFO 15377 was used as the $B$. circulans group $\mathrm{G}$ reference strain (20). The low levels of DNA relatedness with the reference strains (range, 0 to $18 \%$ ) strongly suggested that the five new isolates did not belong to the previously described species.

The five new chitinolytic isolates were divided into two groups on the basis of physiological and biochemical charac-

TABLE 2. Differential phenotypic characteristics of the new chitinolytic isolates

\begin{tabular}{|c|c|c|c|c|c|}
\hline Characteristic & Strain EAG-1 & Strain EAG-2 & Strain EAG-5 ${ }^{\mathrm{T}}$ & Strain EAG-3 ${ }^{\mathrm{T}}$ & Strain EAG-4 \\
\hline \multicolumn{6}{|l|}{ Colony morphology } \\
\hline Color & Creamy & Pale brown & Creamy & Pale brown & Pale yellow \\
\hline Form & Circular & Circular & Circular & Irregular & Irregular \\
\hline Elevation & Convex & Convex & Convex & Raised & Raised \\
\hline Margin & Entire & Entire & Entire & Undulate & Undulate \\
\hline Gram reaction & $\mathrm{V}^{a}$ & - & V & $\mathrm{V}$ & $\mathrm{V}$ \\
\hline Arrangement of flagella & ND & Peritrichous & Peritrichous & Peritrichous & Peritrichous \\
\hline Oxidase activity & + & + & + & + & - \\
\hline Voges-Proskauer test & - & - & - & $\mathrm{W}$ & $\mathrm{W}$ \\
\hline \multicolumn{6}{|l|}{ Acid produced from: } \\
\hline L-Arabinose & + & + & + & - & - \\
\hline D-Xylose & + & + & + & - & - \\
\hline D-Mannitol & + & + & + & - & - \\
\hline \multicolumn{6}{|l|}{ Hydrolysis of: } \\
\hline Casein & - & + & + & - & + \\
\hline Gelatin & + & + & + & - & + \\
\hline Starch & + & + & + & - & - \\
\hline \multicolumn{6}{|l|}{ Growth at: } \\
\hline $45^{\circ} \mathrm{C}$ & + & + & + & - & - \\
\hline $50^{\circ} \mathrm{C}$ & + & + & - & - & - \\
\hline $55^{\circ} \mathrm{C}$ & - & - & - & - & - \\
\hline
\end{tabular}

"V, variable; -, negative; +, positive; ND, not determined; W, weakly positive. 
TABLE 3. Major menaquinone and cellular fatty acid compositions of the new chitinolytic isolates

\begin{tabular}{|c|c|c|c|c|c|c|c|c|c|c|c|}
\hline \multirow{3}{*}{ Strain } & \multirow{3}{*}{$\begin{array}{c}\text { Major } \\
\text { quinone }^{a}\end{array}$} & \multicolumn{10}{|c|}{ Fatty acid composition (\% of total cellular fatty acids) } \\
\hline & & \multicolumn{9}{|c|}{ Saturated acids } & \multirow{2}{*}{ Unknown $^{h}$} \\
\hline & & $\mathrm{C}_{14}$ & $\mathrm{C}_{15}$ & $\mathrm{C}_{16}$ & iso- $\mathrm{C}_{14}$ & iso- $_{15}$ & iso- $_{16}$ & iso- $_{17}$ & anteiso- $\mathrm{C}_{15}$ & anteiso- $\mathrm{C}_{17}$ & \\
\hline \multicolumn{12}{|c|}{ Group 1 strains } \\
\hline EAG-1 & MK-7 & 1.2 & 0.8 & 12.6 & 1.8 & 5.5 & 8.4 & 5.6 & 53.0 & 10.0 & 2.3 \\
\hline EAG-2 & MK-7 & 1.8 & 0 & 10.7 & 3.0 & 5.2 & 12.3 & 2.4 & 52.3 & 7.8 & 4.5 \\
\hline EAG-5 $5^{\mathrm{T}}$ & MK-7 & 1.0 & 0 & 16.5 & 1.2 & 5.7 & 5.9 & 8.0 & 49.6 & 10.6 & 1.5 \\
\hline \multicolumn{12}{|c|}{ Group 2 strains } \\
\hline EAG-3 $3^{\mathrm{T}}$ & MK-7 & 1.7 & 0 & 21.3 & 1.7 & 0 & 4.2 & 3.4 & 58.0 & 7.8 & 1.4 \\
\hline EAG-4 & MK-7 & 3.2 & 0 & 16.6 & 3.2 & 0 & 7.4 & 2.5 & 59.0 & 5.1 & 3.7 \\
\hline
\end{tabular}

a MK-7, menaquinone with seven isoprene units.

${ }^{b}$ Nonpolar acid.

teristics. Group 1 consisted of strains EAG-1, EAG-2, and EAG- $5^{\mathrm{T}}$, which produced acid from $\mathrm{L}$-arabinose, D-xylose, and D-mannitol, hydrolyzed starch, grew at $45^{\circ} \mathrm{C}$, and were negative in the Voges-Proskauer test. Group 2 consisted of strains EAG $-3^{\mathrm{T}}$ and EAG-4, did not produce acid from L-arabinose, $\mathrm{D}$-xylose, and D-mannitol, did not hydrolyze starch, did not grow at $45^{\circ} \mathrm{C}$, and were positive in the Voges-Proskauer test. These groups were confirmed by the results of a DNA-DNA hybridization study. The members of each group exhibited high levels of DNA relatedness with each other (89 to $105 \%$ ) but low levels of DNA relatedness with members of the other group (7 to $18 \%$ ) (Table 4). These results indicated that the two groups correspond to two independent species. It should be noted that the group 1 strains were isolated from garden soil samples obtained in Matsuyama, Ehime Prefecture, and the group 2 strains were isolated from forest soil samples obtained in Kaya, Kagoshima Prefecture. The physiological and biochemical criteria used to distinguish these two groups from
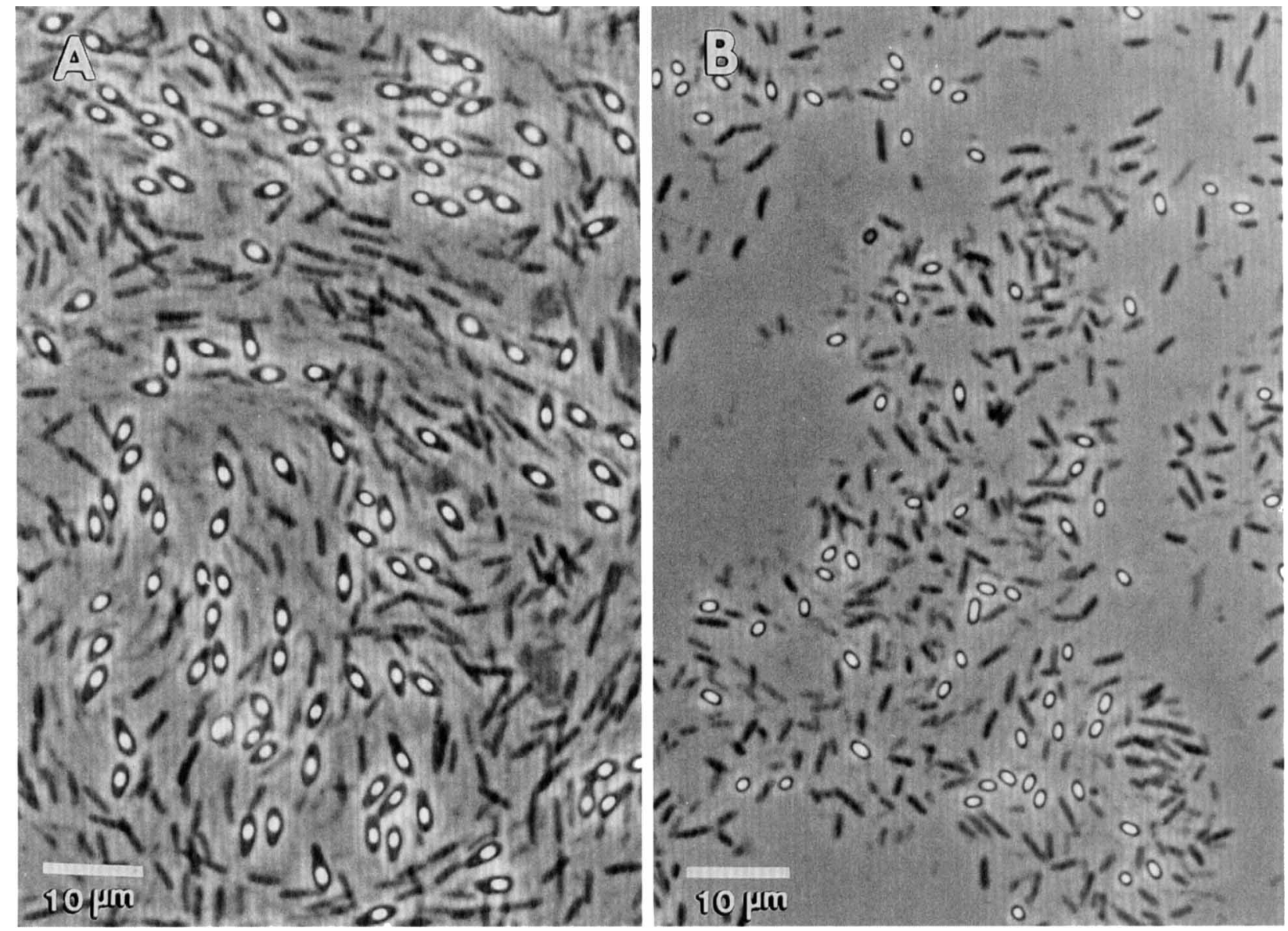

FIG. 1. Phase-contrast micrographs of sporulating cells of B. ehimensis IFO $15659^{\mathrm{T}}$ (A) and B. chitinolyticus IFO $15660^{\mathrm{T}}$ (B) grown on soil extract agar containing $0.5 \%$ peptone, $0.3 \%$ meat extract, $0.2 \%$ yeast extract, $1.5 \%$ agar, and $50 \%$ soil extract $(\mathrm{pH} 7.0)$. The cultures were incubated for 3 days at $30^{\circ} \mathrm{C}$. The soil extract was prepared as follows: $400 \mathrm{~g}$ of farm soil in 1 liter of tap water was autoclaved for $30 \mathrm{~min}$, the solids were removed by filtration, and then the filtrate was autoclaved for 20 min on each of 2 successive days. 
TABLE 4. Levels of DNA relatedness between the new chitinolytic isolates and Bacillus reference strains

\begin{tabular}{|c|c|c|c|c|c|c|}
\hline \multirow{2}{*}{ Strain } & \multirow{2}{*}{$\underset{(\mathrm{mol} \%)^{i t}}{\mathrm{G}+\mathrm{C} \text { content }}$} & \multicolumn{5}{|c|}{$\%$ Similarity with labeled DNA from: } \\
\hline & & Strain EAG-1 & Strain EAG-2 & Strain EAG-5 ${ }^{\mathrm{T}}$ & Strain EAG-3 $3^{\mathrm{T}}$ & Strain EAG-4 \\
\hline Bacillus subtilis IFO $13719^{\mathrm{T}}$ & 44.1 & 4 & 1 & 5 & 9 & 18 \\
\hline Bacillus agri IFO $15538^{\mathrm{T}}$ & 52.6 & 1 & 12 & 1 & 13 & 5 \\
\hline Bacillus borstelensis IFO $15714^{\mathrm{T}}$ & 51.3 & 2 & 6 & 8 & 8 & 5 \\
\hline Bacillus centrosporus IFO $15540^{\top}$ & 50.3 & 4 & 0 & 0 & 6 & 0 \\
\hline Bacillus choshinensis IFO $15518^{\mathrm{T}}$ & 49.1 & 7 & 0 & 1 & 13 & 0 \\
\hline Bacillus lautus IFO $15380^{\mathrm{T}}$ & 50.2 & 9 & 4 & 8 & 2 & 7 \\
\hline Bacillus parabrevis IFO $12334^{\mathrm{T}}$ & 50.0 & 12 & 0 & 9 & 14 & 10 \\
\hline Bacillus thiaminolyticus IFO $15656^{\mathrm{T}}$ & 53.5 & 9 & 12 & 18 & 15 & 6 \\
\hline Bacillus sp. strain IFO 15377 & 50.2 & 5 & 17 & 3 & 13 & 6 \\
\hline EAG-1 & 54.3 & 100 & 91 & 104 & 13 & 7 \\
\hline EAG-2 & 52.9 & 91 & 100 & 98 & 17 & 13 \\
\hline EAG-5 $5^{\mathrm{T}}$ & 54.9 & 89 & 97 & 100 & 18 & 11 \\
\hline $\mathrm{EAG}-3^{\mathrm{T}}$ & 51.3 & 9 & 14 & 9 & 100 & 105 \\
\hline EAG-4 & 52.8 & 7 & 15 & 7 & 104 & 100 \\
\hline
\end{tabular}

${ }^{a}$ Determined by HPLC.

seven other species that are mesophilic and have $\mathrm{G}+\mathrm{C}$ contents of more than $49 \mathrm{~mol} \%$ are shown in Table 5. Chitindegrading activity was found in $B$. thiaminolyticus IFO $15656^{\mathrm{T}}$ but not in the type strains of the other six species studied.

The results of this study demonstrated that the five chitinolytic isolates could be distinguished from all previously described Bacillus species and warrant new taxa. Therefore, below we describe two new species for the group 1 and 2 strains, Bacillus ehimensis and Bacillus chitinolyticus, respectively.

Description of Bacillus ehimensis sp. nov. Bacillus ehimensis (e.hi.men'sis. M. L. adj. ehimensis, referring to Ehime Prefecture, Japan, the source of the soil samples from which the organisms were isolated). Cells are rod shaped ( 0.4 to 0.6 by 1.7 to $5 \mu \mathrm{m})$. The gram reaction is usually positive, although a number of cells are gram negative. Motile by means of peritrichous flagella. Ellipsoidal spores are formed in swollen sporangia. Catalase and oxidase are produced. Aerobic. Acethylmethylcarbinol is not produced. The $\mathrm{pH}$ in Voges-Proskauer broth ranges from 5.8 to 6.3. Nitrate is reduced to nitrite. Acid, but no gas, is produced from D-glucose, L-arabinose, D-xylose, and D-mannitol. Gelatin and starch are hydrolyzed. Hydrolysis of casein is variable. Chitin is decomposed. Citrate and propinate are not utilized. The optimum growth temperature ranges from 28 to $40^{\circ} \mathrm{C}$; the maximum growth temperature ranges from 50 to $53^{\circ} \mathrm{C}$; and the minimum growth temperature ranges from 18 to $20^{\circ} \mathrm{C}$. The $\mathrm{G}+\mathrm{C}$ content of the DNA ranges from 52.9 to $54.9 \mathrm{~mol} \%$. Strains were isolated from garden soil samples obtained in Matsuyama, Ehime Prefecture, Japan.

The type strain is strain IFO 15659 (= EAG-5).

Description of Bacillus chitinolyticus sp. nov. Bacillus chitinolyticus (chi.ti.no.ly'ti.cus. M. L. n. chitinum, chitin; M. L. adj. lyticus, dissolving; M. L. adj. chitinolyticus, decomposing chitin). Cells are rod shaped $(0.4$ to 0.6 by 1.7 to $3 \mu \mathrm{m})$. The gram reaction is usually positive, although a number of cells are gram negative. Motile by means of peritrichous flagella. Ellipsoidal spores are formed in swollen sporangia. Catalase is

TABLE 5. Characteristics that differentiate B chitinolyticus, B. ehimensis, and related Bacillus species

\begin{tabular}{|c|c|c|c|c|c|c|c|c|c|}
\hline Characteristic & $\begin{array}{l}\text { Bacillus } \\
\text { ehimensis }^{a}\end{array}$ & $\begin{array}{c}\text { Bacillus } \\
\text { chitinolyticus }^{t}\end{array}$ & $\begin{array}{l}\text { Bacillus } \\
\text { thiaminolyticus }^{b}\end{array}$ & $\begin{array}{c}\text { Bacillus } \\
\text { agri }^{-}\end{array}$ & $\begin{array}{l}\text { Bacillus } \\
\text { lautus }^{d}\end{array}$ & $\begin{array}{c}\text { Bacillus } \\
\text { centrosporus }^{c}\end{array}$ & $\begin{array}{c}\text { Bacillus } \\
\text { parabrevise }\end{array}$ & $\begin{array}{c}\text { Bacillus } \\
\text { chosinensis }^{e}\end{array}$ & $\begin{array}{c}\text { Bacillus } \\
\text { borstelensisf }\end{array}$ \\
\hline Anaerobic growth & $-g$ & - & + & - & + & - & - & - & - \\
\hline $\begin{array}{l}\text { Voges-Proskauer test } \\
\text { pH of Voges-Proskauer broth }\end{array}$ & + & + & + & - & + & - & - & - & - \\
\hline$<6.0$ & + & + & + & - & + & - & - & - & - \\
\hline$>7.2$ & - & - & - & + & - & + & + & + & + \\
\hline Reduction of nitrate & + & + & + & - & + & $\mathrm{d}$ & + & - & + \\
\hline Arabinose & + & - & $\mathrm{d}$ & $\mathrm{d}$ & + & - & - & - & - \\
\hline Glucose & + & + & + & + & + & + & + & + & $\mathrm{d}$ \\
\hline Mannitol & + & - & $\mathrm{d}$ & + & + & + & + & $\mathrm{d}$ & - \\
\hline Xylose & + & - & - & - & + & - & - & - & - \\
\hline \multicolumn{10}{|l|}{ Hydrolysis of: } \\
\hline Chitin $^{a}$ & + & + & + & - & - & - & - & - & - \\
\hline Casein & + & $\mathrm{d}$ & + & + & - & - & + & - & + \\
\hline Gelatin & + & $\mathrm{d}$ & ND & + & ND & ND & + & - & + \\
\hline $\mathrm{G}+\mathrm{C}$ content $(\mathrm{mol} \%)$ & $52-55$ & $51-53$ & $52-54$ & $52-55$ & $50-52$ & $49-51$ & $50-53$ & $49-50$ & $50-52$ \\
\hline
\end{tabular}

"Data from this study.

${ }^{b}$ Data from reference 18 .

c Data from reference 19.

${ }^{d}$ Data from reference 17

'Data from reference 30.

${ }^{f}$ Data from reference 28. 
produced. Aerobic. Acetylmethylcarbinol is produced. The $\mathrm{pH}$ in Voges-Proskauer broth ranges from 5.4 to 5.6. Nitrate is reduced to nitrite. Acid, but no gas, is produced from D-glucose. No acid is produced from L-arabinose, D-xylose, and D-mannitol. Hydrolysis of casein and hydrolysis of gelatin are variable. Starch is not hydrolyzed. Chitin is decomposed. Citrate and propionate are not utilized. The optimum growth temperature ranges from 25 to $37^{\circ} \mathrm{C}$; the maximum growth temperature ranges from 42 to $45^{\circ} \mathrm{C}$; and the minimum growth temperature ranges from 18 to $20^{\circ} \mathrm{C}$. The $\mathrm{G}+\mathrm{C}$ content of the DNA ranges from 51.3 to $52.8 \mathrm{~mol} \%$. Strains were isolated from forest soil samples obtained in Kaya, Kagoshima Prefecture, Japan.

The type strain is strain IFO 15660 (= EAG-3).

\section{REFERENCES}

1. Ash, C., F. G. Priest, and M. D. Collins. 1993. Molecular identification of rRNA group 3 bacilli (Ash, Farrow, Wallbanks and Collins) using a PCR probe test. Antonie Leeuwenhoek 64:253-260.

2. Baumann, P., M. J. Gauthier, and L. Baumann. 1984. Genus Alteromonas Baumann, Baumann, Mandel and Allern 1972, p. 343-352. In N. R. Krieg and J. G. Holt (ed.), Bergey's manual of systematic bacteriology, vol. 1. The Williams \& Wilkins Co., Baltimore.

3. Baumann, P., and R. H. W. Schubert. 1984. Family II. Vibrionaceae Veron 1965, p. 516-550. In N. R. Krieg and J. G. Holt (ed.), Bergey's manual of systematic bacteriology, vol. 1. The Williams \& Wilkins Co., Baltimore.

4. Berger, L. R., and D. M. Reynolds. 1958. The chitinase system of a strain of Streptomyces griseus. Biochim. Biophys. Acta 29:522-534.

5. Claus, D., and R. C. W. Berkeley. 1986. Genus Bacillus Cohn 1872, p, 1105-1139. In P. H. A. Sneath, N. S. Mair, M. E. Sharpe, and J. G. Holt (ed.), Bergey's manual of systematic bacteriology, vol. 2. The Williams \& Wilkins Co., Baltimore.

6. Cody, R. M. 1989. Distribution of chitinase and chitobiase in Bacillus. Curr. Microbiol. 19:201-205.

7. Cowan, S. T., and K. J. Steel. 1965. Manual for the identification of medical bacteria. Cambridge University Press, London.

8. Ezaki, T., Y. Hashimoto, and E. Yabuuchi. 1989. Fluorometric deoxyribonucleic acid-deoxyribonucleic acid hybridization in microdilution wells as an alternative to membrane filter hybridization in which radioisotopes are used to determine genetic relatedness among bacterial strains. Int. J. Syst. Bacteriol. 39:224-229.

9. Farrow, J. A. E., C. Ash, S. Wallbanks, and M. D. Collins. 1992. Phylogenetic analysis of the genera Planococcus, Marinococcus and Sporosarcina and their relationships to members of the genus Bacillus. FEMS Microbiol. Lett. 93:167-172.

10. Goodfellow, M. 1992. The family Streptosporangiaceae, p. 1115-1138. In A. Balows, H. G. Trüper, M. Dworkin, W. Harder, and K.-H. Schleifer (ed.), The prokaryotes, 2nd ed., vol. II. Springer-Verlag, New York.

11. Gordon, R. E., W. C. Haynes, and C. H.-N. Pang. 1973. The genus Bacillus. Agriculture Handbook No. 427. U.S. Goversment Printing Office, Washington, D.C.
12. Jeuniaux, C. 1966. [III]Chitinase. Methods Enzymol. 8:644-650.

13. Mesbah, M., U. Premachandran, and W. B. Whitman. 1989. Precise measurement of the $\mathrm{G}+\mathrm{C}$ content of deoxyribonucleic acid by high-performance liquid chromatography. Int. J. Syst. Bacteriol. 39:159-167.

14. Miller, J. H. 1972. Experiments in molecular genetics. Cold Spring Harbor Laboratory, Cold Spring Harbor, N.Y.

15. Molise, E. M., and C. H. Drake. 1973. Chitinolysis by serratiae, including Serratia liquefaciens (Enterobacter liquefaciens). Int. J. Syst. Bacteriol. 23:278280.

16. Monreal, J., and E. T. Reese. 1969. The chitinase of Serratia marcescens. Can. J. Microbiol. 15:689-696.

17. Nakamura, L. K. 1984. Bacillus amylolyticus sp. nov., nom. rev., Bacillus lautus sp. nov., nom. rev., Bacillus pabuli sp. nov., nom. rev., and Bacillus validus sp. nov., nom, rev. Int. J. Syst. Bacteriol, 34:224-226.

18. Nakamura, L. K. 1990. Bacillus thiaminolyticus sp. nov., nom. rev. Int. J. Syst. Bacteriol. 40:242-246.

19. Nakamura, L. K. 1993. DNA relatedness of Bacillus brevis Migula 1900 strains and proposal of Bacillus agri sp. nov., nom. rev., and Bacillus centrosporus sp. nov., nom. rev. Int. J. Syst. Bacteriol. 43:20-25.

20. Nakamura, L. K., and J. Swezey. 1983. Deoxyribonucleic acid relatedness of Bacillus circulans Jordan 1890 strains. Int. J. Syst. Bacteriol. 33:703-708.

21. Priest, F. G., M. Goodfellow, and C. Todd. 1988. A numerical classification of the genus Bacillus. J. Gen. Microbiol. 134:1847-1882.

22. Reichenbach, H. 1989. Order 1. Cytophagales Leadbetter 1974, p. 2011-2083. In J. T. Staley, M. P. Bryant, N. Pfennig, and J. G. Holt (ed.), Bergey's manual of systematic bacteriology, vol. 3. The Williams \& Wilkins Co., Baltimore.

23. Reichenbach, H. 1992. The genus Lysobacter, p. 3256-3275. In A. Balows, H. G. Trüper, M. Dworkin, W. Harder, and K.-H. Schleifer (ed.), The prokaryotes, 2nd ed., vol. IV. Springer-Verlag, New York.

24. Reichenbach, H. 1992. The genus Herpetosiphon, p. 3785-3805. In A. Balows, H. G. Trüper, M. Dworkin, W. Harder, and K.-H. Schleifer (ed.), The prokaryotes, 2nd ed., vol. IV. Springer-Verlag, New York.

25. Robbins, P. W., C. Albright, and B. Benfield. 1988. Cloning and expression of a Streptomyces plicatus chitinase (chitinase-63) in Escherichia coli. J. Biol. Chem. 263:443-447.

26. Saito, H., and K. Miura. 1963. Preparation of transforming deoxyribonucleic acid by phenol treatment. Biochim. Biophys. Acta 72:619-629.

27. Sangkhobol, V., and V. B. D. Skerman. 1981. Chitinophaga, a new genus of chitinolytic myxobacteria. Int. J. Syst. Bacteriol. 31:285-293.

28. Shida, O., H. Takagi, K. Kadowaki, S. Udaka, L. K. Nakamura, and K. Komagata. 1995. Proposal of Bacillus reuszeri sp. nov., Bacillus formosus sp. nov., nom. rev., and Bacillus borstelensis sp. nov., nom. rev. Int. J. Syst. Bacteriol. 45:93-100.

29. Suzuki, K., and K. Komagata. 1983. Taxonomic significance of cellular fatty acid composition in some coryneform bacteria. Int. J. Syst. Bacteriol. 33: 188-193.

30. Takagi, H., O. Shida, K. Kadowaki, K. Komagata, and S. Udaka. 1993. Characterization of Bacillus brevis with descriptions of Bacillus migulanus sp. nov., Bacillus choshinensis sp. nov., Bacillus parabrevis sp. nov., and Bacillus galactophilus sp. nov. Int. J. Syst. Bacteriol. 43:221-231.

31. Watanabe, T., W. Oyanagi, K. Suzuki, and H. Tanaka. 1990. Chitinase system of Bacillus circulans WL-12 and importance of chitinase A1 in chitin degradation. J. Bacteriol. 172:4017-4022. 